\title{
Career forms: Organizational, gig, and in-between
}

\author{
Sambhavi Lakshminarayanan \\ Simon Best \\ Department of Business Administration \\ School of Business \\ Medgar Evers College, City University of New York, USA
}

\section{Keywords}

Career, Gig Economy, Classic, Boundaryless, Protean, Organization

\begin{abstract}
The nature of business-related careers, and particularly organizational ones, has changed drastically over the last many years. Non-traditional careers of the past are rapidly becoming the norm. Classic career management literature focused on managing and being successful in organizational careers. However, the environment has changed, and researchers have pointed out that careers now can be viewed as being organizational, semi-organizational and gig-economy related. The common thread through the new career forms is the increased responsibility on individuals to manage their careers. In particular, the gig-economy points to a de-linking of organizations with people doing organizational work, by the latter being viewed as independent contractors rather than employees. In this paper, we present prior work on career forms and models, both within and outside of organizational boundaries. Further, we propose a theoretical framework to view these career forms in the context of current organizational settings.
\end{abstract}

\section{Introduction}

Individuals accumulate work experiences over their lifetimes and do so by following different pathways. They could work for their own enterprises or other organizations. These organizations could be for-profits, nonprofits or governmental. The focus of this paper is on careers related to for-profit businesses, both in the corporate organizational and in the self-employed categories.

Businesses in the U.S. have completely upended themselves structurally and functionally, driven by twin engines of technological advances and their willingness to dynamically restructure to fit changing strategic concerns. Thus, a "typical" organizational career that once might have been housed in just one firm over an individual's working life has become fractured and potentially spread over several organizations. Simultaneously, there has been the rise of the non-organizational, "gig" economy that provides opportunity for individual contractual work. Regardless of the form, the onus is now on individuals to continually manage their careers.

\section{The Employment Landscape: Business Organizations and the Gig Economy}

Over the last few decades, U.S. businesses have faced increasing pressure to perform financially and compete globally. Their response has been to reformulate the meaning of organizational work and alter the social contract they had with their workforce. This coincided with reduction in power of workers' unions.

Employees at all levels have been affected by the permanent change's businesses have been making through constant re-evaluation, restructuring, and outsourcing. Whether it is far-shoring or near-shoring, outsourcing has disrupted organizational careers, since it is irrevocably tied with downsizing or lay-offs (Peirpel and Baruch, 1997). These widespread and long-term practices have completely changed organizational careers, with lifetime or even long-term employment almost disappearing from the picture.

At the same time, there has been a growth in the number of people working in temporary and unstructured employment, commonly referred to as the "gig economy" This kind of employment differs from traditional self-owned businesses and is more akin to traditional contractors. However, in contrast to the latter, in the gig economy, the services provided are typically housed within large organizations. Many factors have contributed to the growth of the gig economy in the U.S. (Strauss, 2017; Manyika, et al., 2016; Gig Economy, n.d). A leading factor is workforce mobility linked to digital work and related 
decoupling of work and job locations. An increasing number of workers, unemployed, underemployed, or inactive, have sought gig work, either as primary or as supplemental income. Interestingly, Gig economy workers could include even executive-level professionals, who might participate while holding to their traditional 9-to-5 primary jobs. Thus, the phenomenon has affected not only lower levels of organizations but even executive levels (Best, 2017).

The reasons for participating in the gig economy are varied. Some workers who experienced frustration with seeking full-time organizational employment in the last recession decided to turn instead to the freelance market. A decline in domestic pension programs, resulting in reduced retirement savings for older members of the workforce, caused some in this group to seek temporary and self-scheduled work. Many employees, viewing organizational turbulence, aspired to become independent. Some valued the freedom of choice of work location. Finally, some people have simply liked the flexibility of gig work to earn an income.

A specific group, who can be referred to as the "sandwich generation" has faced hurdles regarding their careers. This is due to their life situation. Not only do they need to work and pursue their careers, they need to take care of their elderly parents and their children at the same time (Ansberry, 2020). The gig economy allows them to prolong their careers at their own pace, place, and time, by sharing their knowledge and skills, while earning income for the effort.

Finally, the rise of the gig economy has also been fueled by increased demand from both consumers and organizations for independently provided services. Presumably, these services have lower prices and increased convenience as selling points.

\section{The Employment Landscape: Society and Workforce Groups}

There is no doubt that social changes interact strongly with organizational ones. The composition of the societal workforce impacts that of a business, as does the socio-legal environment. For some countries, demographic changes cause workforce contraction, with a ripple effect on the job market and employee careers. Factors impacting careers include the rate of labor displacement, government labor policies, and population growth or decline. Two critical aspects of the population are: age structure and the speed of population aging. These are affected by fertility rates as well as mortality rates and life expectancy in the population. A steady decline in annual birth rates, sometimes as the result of governmental policy (such as China's one-child policy), can result in altered workforce composition. For instance, this can result in a greater presence of mature employees. A significant social change has been the increase in women pursuing careers, with certain professions categorized as "pink" jobs while those of men being referred to as "blue" (The Economist 2019). Finally, an important influence is that of migration (Reynauld and Miccolli, 2019), as determined by immigration policies. All of these could skew existing employee pools.

The movement of workers across countries, commonly tied with the idea of globalization, has resulted in a diverse workforce in the U.S. This workforce broadly adheres to certain workplace values, expectations, lifestyles, and individual careers --- past and developing -- depending on the geographical context. Even with the shortage of certain technical skills in some sections of the labor force in the industrialized world, automation, machine learning, and algorithms have completely transformed the way many of today's jobs are done. Modifications to careers necessarily occur. The bookend to this is the importance of attracting, maintaining, developing, and upskilling internal labor forces. A complex combination of adjusting for market realities, with labor shortages and need for enhanced organizational performance and productivity gains have ensued. These concerns are reflected in the generational makeup of the workforce and changes in structured employment relationships.

An interesting feature of the changing workforce is the presence of multiple age cohorts working as peers. There has been an increasing number of people working well into what used be retirement ages. The main reasons for this are banking failures and resultant financial crises, along with reduction of job benefits. This continuing presence of older workers could be controversial. An upside is the retention of the talent and skills of older workers with organizational memory who could guide and coach younger workers and new hires. Younger workers could contribute to new thinking and technological knowledge. However, Fairless (2019) contends that older workers entering Europe's labor market in general, and in the hospitality industry, in particular, do so at the expense of career opportunities for younger workers. 
This multi-cohort workforce can be divided into generational groups as: 1) Traditionalists, those born before 1946; 2) Baby Boomers those born between 1946 and 1964; 3) Generation X, those born between 1965 and 1976; 4) Generation Y, or Millennial, those born between 1977 and 1997; and 5) Generation Z, those born after 1997 (Grensing-Pophal, 2018). The groupings reflect differences between groups in terms of their attitudes, expectations, strengths, and limitations as workers.

\section{Classic Career Models}

A career can be understood as a sequence of work experiences over a lifetime (Greenhaus and Kossek, 2014). These experiences could include professional, semi-professional and personal activities (Sullivan and Baruch, 2009).

The classic approach to career planning began with identifying an individual's vocational preferences, considered as a reflection of a person's attitude towards career-related contexts, situations, and outcomes (Nye et al., 2012, p. 385). Holland attempted to classify individuals through six vocational identities - realistic, investigative, artistic, social, enterprising, conventional" (Nye et al., 2012). Career counselors directed individuals to careers thought to be an appropriate fit based on such vocation related information. Original career planning models recognized that individuals differ in interests, aptitudes, and values (Super, 1953, p. 187). Thus, not every career is a good fit for every person. At the same time, it was understood that, for every individual, there is a variety of jobs that he or she could succeed in (Super, 1953). Thus, the emphasis in career planning was on making the right career choice, with the default assumption that the individual would remain in such a chosen career for an extended period of time.

How individuals made career decisions was also studied. According to Gottfredson's Theory of Circumscription and Compromise, an individual made career choice through a process of elimination, guided by self-concept, removing those that were not acceptable or possible (Leung, 2008). Bandura's Social Cognitive Theory proposed that an individual chose a career based on feelings of self-efficacy. Both theories have stood the test of time and apply equally well to current organizational environments, even as career choices become more frequent over an individual's lifetime.

For a career anchored in an organization, career development followed career choice. A typical organizational career would move within the hierarchy, either vertically or laterally. In Weber's ideal of a bureaucratic organization, movement such as selection, placement, and promotion would be based on technical competence (Clarke, 2013). However, the reality is more complex and much of careerdevelopment research focused on negotiating the organizational workplace. Literature addressed both individual-level career planning and organization-level management processes (Greco and Kraimer, 2019) since organizations were assumed to have a vested interest in developing their employees. Thus, a traditional organizational career was defined in terms of the relationship, and the underlying social contract, between an individual and the employing organization (Sullivan and Baruch, 2009, p.1542). The underlying assumption was of a stable organizational structure and longtime employment.

Traditional career growth models followed the "logic of Advancement'. Ambitious and careerfocused employees would move up the organizational hierarchy through a sequence of positions (Kanter, 1989; Clarke, 2013, p. 685). Career advancement depended on various factors, some of which were specific to the individual and others organizational. Ambition, couched in the organizational context (Fels, 2004), and desire for advancement was a necessary individual characteristic. Different organizations could have different career progression models. Some might favor advancement based on length of tenure, namely seniority. Most U.S. companies are assumed to be 'contest' oriented, where individuals are chosen for progress up the hierarchy based on competition of some sort (Ishida et al., 2002). Advancement that was mostly of insiders could be facilitated by the organization hiring few outsides beyond entry levels, promoting 'from within' and minimizing attrition.

Basic career competencies such as skills and job-related knowledge, personal motivation and contacts among coworkers were considered as the how, why and who aspects of an organizational work that were relevant for all employees, regardless of specific jobs (Hirschi, 2012). Further, career progression through the hierarchy was tied to aspects such as - kind of work done, visibility and perception. Work that was more central to an area or department, and eventually to the organization, was likely to lead to advancement rather than work considered either as a support function or not that critical. Simply doing the work or even doing it very well, was not sufficient to gain advancement; others had to know about it 
as well, leading to the concept of 'visibility' in the organization. Individuals could and needed to, make others aware of their performance and potential. This could be done directly, as in claiming ownership of work done, or indirectly through mentors and sponsors. This was also related to having connections and relationships at work, both to inform and be informed.

The work that an individual did was closely tied to organizational success. For instance, taking on 'challenging' or difficult assignments and delivering work output in them would be favorably viewed. Often international ventures were critical to a company's overall strategy and managing them well was considered a benchmark of organizational success (Yan, Zhu, and Hall, 2002). Thus, international assignments were often considered essential steps for top-level executives.

\section{New Career Models and a Proposed Framework}

Career management could be viewed as a process through which individuals gain knowledge both of themselves and their work environments, determine meaningful goals, and decide on career strategies. This is a dynamic process, where the individuals get feedback regarding performance and progress to repeat the cycle (De Vos and Cambre, 2017, p. 504). This view de-couples the individual from the organization. Such a general focus on individuals and career management, factoring in organizational changes, has led to new views of careers.

One approach was to identify three parameters of career planning as Authenticity, Balance, and Challenge and view careers as focusing on one of these at a time. Authenticity referred to the sense of being true to oneself, which could be interpreted in different ways, such as being true to one's identities or values. Balance referred to making choices so the different aspects of life so the whole made sense for the individual. Challenge had to do with doing something an individual might find difficult and would need to invest in learning, although it would lead to more control and autonomy (Sullivan and Mainiero, 2007). At different points in an individual's career, he or she would focus on one of these three parameters.

An Alpha career pattern would focus on - Challenge, Authenticity, Balance (Sullivan and Mainiero, 2007, p. 238) and would align with traditional organizational career paths and upward mobility. As a contrast, Beta careers would focus on - Challenge, Balance, Authenticity, and represent choices of individuals who (might have had to) make adjustments to have a more balanced life (Sullivan and Mainiero, 2007, p. 238). Researchers suggested, somewhat contradictory to traditional career advice, that it may not always be best to pursue alpha, upwardly mobile careers. Organizations may want, and value, Beta careerists as positively contributing to a culture of balance and stability (Sullivan and Mainiero, 2007, p. 268).

Other management scholars claimed that careers have lost traditional features (SidiropoulouDimakakou, Mylonas and Argyropoulou, 2015, p.40). Rather than a linear process of professional advancement and organizational mobility, a modern career is more likely to be an accumulation of various work experiences (Clarke, 2013, p. 685). It can include occupations and experiences in the life of the individual (Super, Tiedeman and Borow, 1961). Thus, careers have become both less linear and less predictable (Hirschi, 2012).

This place the onus of career planning and management on the individual, rather than the organization. Individuals who are comfortable with planning in their everyday lives may be adept at career planning (Gould, 1979). Career planning would require knowledge of skills and requirements for different careers and work environments, as well as an understanding of one's drives, skills, and aptitudes. Broadly, career success has been defined as positive psychological and work-related outcomes (Seibert and Kraimer, 2001). Both extrinsic and intrinsic factors can contribute to a feeling of career success ( $\mathrm{Ng}$ et al., 2005). Typically, organizational indicators of career success have been titles, promotions, and compensation. In the absence of such indicators, individuals have to determine what career success means for them.

In addition to individuals taking on responsibility for their career management, they have to do so in an increasingly uncertain and turbulent business environment (Greenhaus and Kossek, 2014). Organizations used to be collections of full-time employees, and even have had an implicit understanding of long-term employment. However, after a few decades of shift in how (global) business actually function, U.S. organizations now are more likely to have three significant groups of workers - full-time, temporary, and part-time (Hall, 2004). The issue of who constitutes full-time or core could change 
dynamically, depending on strategic decisions. This could result in entire departments or divisions being eliminated, as non-essential to the current strategy.

Two career orientations were identified as prevailing in this environment: Boundaryless and Protean. Both Boundaryless and Protean reflect the changed relationship between employees and organizations.

A boundaryless career spans across different organizations and represents the willingness of an individual to move out of organizational boundaries. Movement can be of two types - 1) psychological, reflecting change in kind of work done and desire for variety and 2) physical, reflecting change in location and organization, but not necessarily the kind of work done (Wiernik and Kostal, 2019). A boundaryless careerist is not attached to a single organization and has career mobility across companies or even industries. Career success could be both extrinsic (need to earn a livelihood) and intrinsic (resonate with internal needs and values).

A Protean career is characterized by career decisions based on the individual's core values. The major success criterion is intrinsic and subjective. Protean careerists are self-driven and may make career choices that need not gain them material gains (Wiernik and Kostal, 2019). Additionally, Protean careerists might even pursue traditional organizational careers if that choice aligned with their core values.

More recently, apprenticeship programs have made an appearance as a new hiring trend in some large companies. Companies such as Bosch, Barclays and IBM have started employing jobseekers without college degrees to fill their entry-level tech positions (Shah, 2020). Such initiatives provide high school graduates an opportunity to embark on work without having to go through the process of getting a college degree. A caveat is that such apprenticeships may be temporary and mutually beneficial work experiences, necessarily ending in organizational careers.

Any extreme of a pure career form might be rare. Some careers that continue to exist like traditional organizational ones are termed post-corporate (Lips-Wiersma and Hall, 2007). However, the general trend appears to be individuals experiencing hybrid careers, characterized by elements of both traditional and non-traditional career concepts. They may want the job security and hierarchical mobility of traditional organizational careers but also non-traditional career development aspects such as boundaryless training and interaction, and a sense of protean well-being (Sullivan and Baruch, 2009 p. 1557). This could be driven by their understanding that an organizational career is more likely a job, and subject to upheaval.

One way to view different career forms is by considering two differentiating variables. The first is the organizational relationship: that is, whether the individual is an employee of the organization, an individual contractor, or an individual contractor under an organizational umbrella. The second is the customer relationship: that is, whether the work is directed to organizational entities or individual consumers. The framework below illustrates this. As mentioned, individual careers can move between the boxes, or even span across them (as in the case of those performing gig jobs on a part-time basis while holding full-time organizational jobs).

Table 1: Framework of Current Career Forms

\begin{tabular}{|l|l|l|}
\hline & Organizational Customer & Individual Consumer \\
\hline Organizational Employee & Traditional organizational career, B-to-B & $\begin{array}{l}\text { Traditional organizational career, B- } \\
\text { to-C }\end{array}$ \\
\hline Individual contractor & $\begin{array}{l}\text { Traditional consultant, supplier, or sub- } \\
\text { contractor }\end{array}$ & Traditional contractor or freelancer \\
\hline $\begin{array}{l}\text { Individual under an } \\
\text { organizational umbrella }\end{array}$ & "Gig economy" B-to-B & $\begin{array}{l}\text { "Gig economy" B-to-C example: } \\
\text { Uber }\end{array}$ \\
\hline
\end{tabular}

While these are actual career forms, we can view Alpha, Beta, Boundaryless, and Protean as career orientations or mind-sets. They more accurately describe the motivations and mindsets that drive individuals in career choices (for example: accepting or declining an overseas assignment) rather than actual interaction with employers and customers.

Our framework provides a theoretical lens through which to view careers. Actual careers can move between the boxes or even be in multiple boxes at the same time. For instance, an individual could have a boundaryless by starting as an organizational employee and moving to being a contractor. An 
individual is can simultaneously be an organizational employee and individual worker under an organizational umbrella.

While this framework is a useful way to view current career forms and shows the role of organizations in careers, it is a theoretical construct that is not prescriptive. It does not explain conditions under which an individual will move from one box (in Table 1) to another, nor the relative merits of doing so. To gain more insights, we would need to identify conditions under which individuals and organizations fit into each of the boxes in the table.

\section{Conclusion}

Changes in career forms are here to stay. The classic organizational career has not disappeared and continues to exist in some form. However, today's employment reality suggests that careers exist on a continuum of fixed, standard employment and fragmented, dynamic gigging activity. Workers may have little choice but to engage in technology-induced job-hopping. The combined work experience could take the form of boundaryless careers or gigging activities, as either the main or supplementary source of income. Thus, over a lifetime, an individual could have jobs straddling several careers, or just one single career but with several jobs and employers.

Career management requires individuals to have a mix of old and new skills. Willingness and ability to do continuous learning is a career survival necessity. Other necessary features are expertise in doing the current job, continual updating of skills needed for the current job, and acquiring skills transferable to other jobs, in case the current job is eliminated or drastically changed. Development of organizing, efficiency, time management, and effective communication skills, all of which used to be under the organization's purview, now have become the individual's responsibility. Mentors and sponsors were found to be key to organizational career success and organizations had mentoring initiatives or even formal matching programs. However, that too has been delegated; individuals now need to develop their networks both within and without organizations and in broader professional arenas since careers are likely to move around.

New career forms present daunting challenges for some and exciting opportunities for others. Knowledge of how to negotiate the landscapes will distinguish the latter from the former. The framework proposed in this paper will aid individuals in understanding career forms and assist in career management.

\section{References}

Ansberry, C. (2020, February 12). "I feel Very Torn between My Child and My Dad." Wall Street Journal. Retrieved from https://www.wsj.com/articles/i-feel-very-torn-between-my-child-and-my-daddemands-intensify-forthe-sandwich-generation-11581507999? $\mathrm{mod}=$ searchresultsandpage $=1$ andpos $=1$

Best, S. (2017). The U. S. Gig Economy: Economic Imposition or Economic Choice. Abrm.com, 8, pp. 60-67.

Clarke, M. (2013, February). The Organizational Career: Not Dead but in Need of Redefinition. The International Journal of Human Resource Management, 24(4), pp. 684-703.

De Vos, A. and Cambre, B. (2017, May-June). Career Management in High-Performing Organizations: A Set-Theoretic Approach. Human Resource Management, 56(3), 501-518, DOI:10.1002/hrm.21786.

Fels, A. (2004). Do Women Lack Ambition? Harvard Business Review. Retrieved from https://hbr.org/2004/04/dowomen-lack-ambition

Gig Economy (n.d.). Gig Economy. WhatIs.com. Retrieved from http://whatis.techtarget.com/definition/gig-economy Gould, S. (1979). Characteristics of Career Planners in Upwardly Mobile Occupations. Academy of Management Journal, 22(3), pp. 539-550.

Greco, L. M. and Kraimer, M. L. (2019). Goal setting in the Career Management Process: An Identity Theory Perspective. Journal of Applied Psychology, Advance online publication. http://dx.doi.org/10.1037/apl0000424

Greenhaus, J. H. and Kossek, E. E. (2014). The Contemporary Career: A Work-Home Perspective. Annual Review of Organizational Psychology and Organizational Behavior, 1, pp. pp. 361-388.

Grensing-Pophal, L. (2018, February 26). Diversity Insight. HR Daily Advisor. Retrieved from https://hrdailyadvisor.blr.com/category/diversity-insight/

Hall, D. T. (2004). The Protean Career: A Quarter-Century Journey. Journal of Vocational Behavior, 65, pp. 1-13.

Hirschi, A. (2012, August). The Career Resources Model: An Integrative Framework for Career Counsellors. British Journal of Guidance and Counselling, 40(4), pp. 369-383. 
Ishida, H., Kuo, H. and Spilerman, S. (2002). Models of Career Advancement in Organizations. European Sociological Review, 18(2), 179-198.

Leung, A. S. (2008). The Big Five Career Theories. In: Athanasou, J.A. and R. Van Esbroeck, R. eds. International Handbook of Career Guidance. Springer Science + Business Media B.V., pp. 115-132.

Lips-Wiersma, M. and Hall, D. T. (2007). Organizational Career Development is Not Dead: A Case Study on Managing the New Career during Organizational Change. Journal of Organizational Behavior, 28, 771-792, DOI: 10.1002/job.446.

Mainiero, L. A. and Sullivan, S. E. (2005). Kaleidoscope careers: An Alternate Explanation for the "Opt-out" Revolution. Academy of Management Executive, 19(1), pp. 106-123.

Manyika, J., Lund, S., Bughin, J., Robinson, K., Mischke, J. and Mahajan, D. (2016). Independent Work: Choice, Necessity, and the Gig Economy. Mckinsey.com. Retrieved from http://www.mckinsey.com/globalthemes/employment-and-growth/independent-work-choice-necessity-and-the-gig-economy

Mulcahy, D. (2017). The Gig Economy. New York: Amacom.

Ng, T. W. H., Eby, L. T., Sorensen, K. L. and Feldman, D. C. (2005) Predictors of Objective and Subjective Career Success: A Meta-Analysis. Personnel Psychology, 58, pp. 367-408.

Nye, C. D., Su, R., Rounds, J. and Drasgow, F. (2012, July). Vocational Interests and Performance: A Quantitative Summary of over 60 Years of Research. Perspectives on Psychological Science, 7(4), pp. 384-403.

Peirpel, M. and Baruch, Y. (1997, Spring). Back to Square Zero: The Post-Corporate Career. Organizational Dynamics, pp. 7-22.

Reynaud, C. and Miccolli, S (2019). Population Ageing in Italy after the 2008 Economic Crisis: A Demographic Approach. Futures, 105, pp. 17-26.

Seibert, S. E. and Kraimer, M. L. (2001). The Five-Factor Model of Personality and Career Success. Journal of Vocational Behavior, 58, pp. 1-21, doi:10.1006/jvbe.2000.1757

Sidiropoulou-Dimakakou, D., Mylonas, K. and Argyropoulou, K. (2015, May). Self-Efficacy in Career Planning: A New Approach to Career Exploration. International Journal of Learning, Teaching and Educational Research, 11(2), pp. 40-54.

Shah, A. (2020, January 30) Seeking Tech Talent, Companies Kickstart Apprenticeship programs. Wall Street Journal. Retrieved from https://www.wsj.com/articles/seeking-tech-talent-companies-kickstart-apprenticeshipprograms-11580396400?mod=hp_minor_pos5

Strauss, K. (2017, February 17). What is Driving the 'Gig' Economy? Forbes.com. Retrieved from https://www.forbes.com/sites/karstenstrauss/2017/02/21/what-is-driving-the-gigeconomy/\#37abfd72653c

Sullivan, S. E. and Mainiero, L. A. (2007). The Changing Nature of Gender Roles, Alpha/Beta Careers and Work-Life Issues: Theory-driven Implications for Human Resource Management. Career Development International, 12(3), pp. 238-263.

Sullivan, S. E. and Baruch, Y. (2009). Advances in Career Theory and Research: A Critical Review and Agenda for Future Exploration. Journal of Management, 36(6), pp. 1542-1571.

Super, D. E. (1953). A Theory of Vocational Development. The American Psychologist, pp. 185-190.

Super, D. E., Tiedeman, D. V. and Borow, H. (1961, September). Vocational Development: A Symposium. Personnel and Guidance Journal, pp. 11-15.

The Economist. (2019, February 16). True Colours: Men Still Pick "Blue" Jobs and Women "Pink" Jobs. The Economist. Retrieved from https://www.economist.com/finance-and-economics/2019/02/16/men-still-pick-blue-jobsand-women-pink-jobs

Wiernik, B. M. and Kostal, J. W. (2019). Protean and Boundaryless Career Orientations: A Critical Review and Metaanalysis. Journal of Counseling Psychology, 66(3), pp. 280-307

Yan, A., Zhu, G. and Hall, D. T. (2002). International Assignments for Career Building: A Model of Agency Relationships and Psychological Contracts. Academy of Management Review, 27(3), pp. 373-391. 